\title{
Vitamin D and the NLRP3 Inflammasome
}

\author{
Matthew Tunbridge ${ }^{1,2, *}$ and Pedro Henrique França Gois 1,2,3 \\ 1 Nephrology Department, Royal Brisbane and Women's Hospital, Herston 4029, Australia; \\ pedro.francagois@health.qld.gov.au \\ 2 Faculty of Medicine, University of Queensland, Brisbane 4072, Australia \\ 3 Conjoint Internal Medicine Laboratory-Kidney Research Group, Queensland Institute of Medical Research, \\ Brisbane 4029, Australia \\ * Correspondence: Matthew.Tunbridge@health.qld.gov.au; Tel.: +61-(07)-3646-8111
}

Received: 1 November 2020; Accepted: 24 November 2020; Published: 27 November 2020

\begin{abstract}
Vitamin D (VD) is a steroid hormone classically known for its key role in maintaining calcium homeostasis in the body. VD also has important immunomodulatory functions. This review explores evidence for a role of VD in attenuating the activation of the nucleotide-binding domain-like receptor protein 3 (NLRP3) inflammasome. Dysregulated and inappropriate NLRP3 inflammasome activation occurs in a range of human diseases, including autoinflammatory disorders, metabolic disorders, and infections. VD appears to mediate its effects by binding of the VD receptor (VDR) to the sensor protein NLRP3, inhibiting deubiquitination and downstream inflammasome assembly. Some early clinical evidence suggests improved outcomes in inflammasome-mediated disorders when VD-deficient patients are treated with supplementation therapy.
\end{abstract}

Keywords: vitamin D; vitamin D receptor; NLRP3; inflammasome; immunomodulation

\section{Introduction}

Vitamin $\mathrm{D}(\mathrm{VD})$ is a multifunctional secosteroid hormone precursor best known for its role in maintaining calcium homeostasis and bone health. However, VD has wide-ranging effects beyond this traditionally understood role, including the regulation of immune responses, inflammation and oxidative stress, and cancer prevention.

$\mathrm{VD}$ is a precursor of the active $1,25(\mathrm{OH})_{2}$-VD and is available endogenously in two major forms-ergocalciferol $\left(\mathrm{VD}_{2}\right)$ and cholecalciferol $\left(\mathrm{VD}_{3}\right) . \mathrm{VD}_{2}$ is available in the diet in a variety of vegetables and fortified foods, while $\mathrm{VD}_{3}$ is present in some animal-based foods. $\mathrm{VD}_{3}$ can also be synthesized in the skin by conversion from 7-dehydrocholesterol in a multi-step ultraviolet-B light-dependent pathway (Figure 1) [1,2].

VD in both forms is transported by the VD-binding protein (VDBP) in plasma to the liver, where it undergoes hydroxylation of the 25 carbon by 25-hydroxylase (a cytochrome P450 enzyme, CYP2R1) to become $25(\mathrm{OH})-\mathrm{VD}_{2}$ or $25(\mathrm{OH})-\mathrm{VD}_{3}[2,3]$. $25(\mathrm{OH})-\mathrm{VD}$ is the major circulating form of $\mathrm{VD}$, the levels of which are measured as markers of overall VD status. A subsequent hydroxylation step on the 1 carbon occurs in the kidney, mediated by $1 \alpha$-hydroxylase (CYP27B1) to create the active form $1,25(\mathrm{OH})_{2}-\mathrm{VD}$ (Figure 1) [2]. Nevertheless, both 25(OH)-VD and 1,25(OH $)_{2}-\mathrm{VD}$ are constituently active and can bind to and activate the VD receptor (VDR) [2]. Hydroxylation of $\mathrm{VD}_{3}$ at alternative positions mediated by CYP11A1 can generate secosteroid metabolites with important actions [4]. Metabolites such as $20(\mathrm{OH})-\mathrm{VD}_{3}$ and $20,23(\mathrm{OH})_{2}-\mathrm{VD}_{3}$ have activity at the VDR and other receptors, including the aryl hydrocarbon receptor (AhR) [5], retinoic acid orphan receptor (ROR)- $\alpha$, and ROR- $\gamma$ [6], producing novel effects including photoprotective and antiproliferative activity $[7,8]$. 


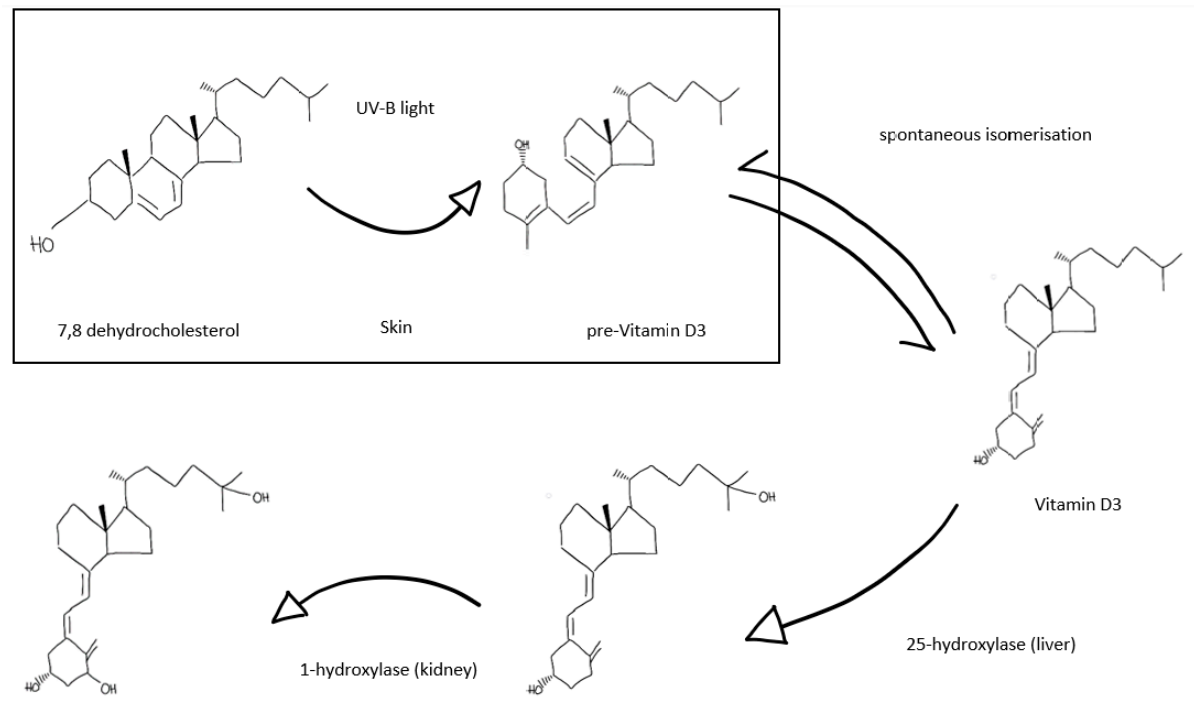

1,25 Vitamin D3

25(OH) Vitamin D3

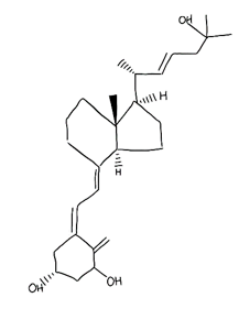

$1,25(\mathrm{OH})$ Vitamin D2

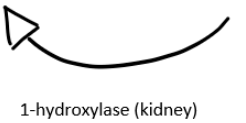

1-hydroxylase (kidney)

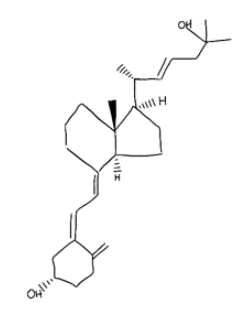

25(OH) Vitamin D2

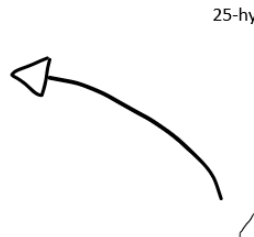

25-hydroxylase (liver)

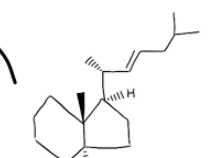

onit

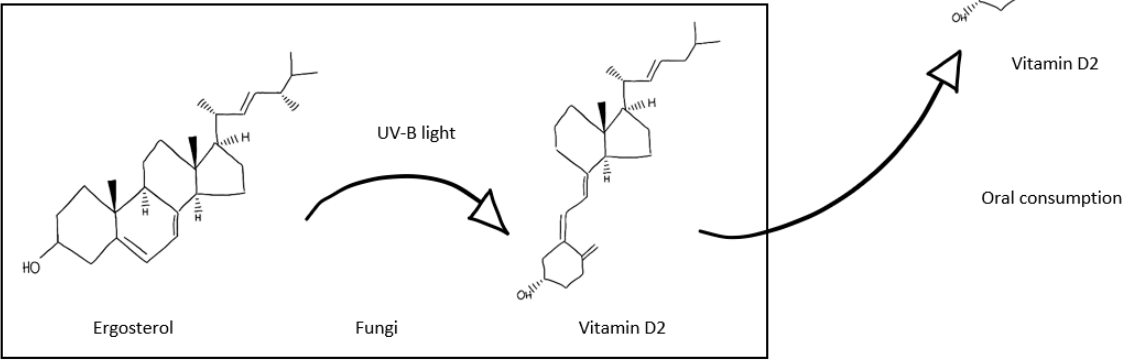

Figure 1. The process of Vitamin $\mathrm{D}_{2}$ and $\mathrm{D}_{3}$ production and activation. 7 dehydrocholesterol is converted to pre-Vitamin $\mathrm{D}_{3}$ in a UV-B-dependent manner in the skin. Pre-Vitamin $\mathrm{D}_{3}$ spontaneously isomerises to Vitamin $\mathrm{D}_{3}$, which is then converted to $25(\mathrm{OH})$-Vitamin $\mathrm{D}_{3}$ by 25 -hydroxylase (primarily CYP2R1) in the liver. The final activation step occurs in the kidney, where 1-hydroxylase (CYP27B1, CYP27A1) creates $1,25(\mathrm{OH})$-Vitamin $\mathrm{D}_{3}$. Vitamin $\mathrm{D}_{2}$ is created from ergosterol in a UV-B-dependent manner in fungi. Following oral consumption, Vitamin $\mathrm{D}_{2}$ undergoes similar activating processes by 25-hydroxylase (CYP2R1) and 1-hydroxylase (CYP27B1). UV-B: ultraviolet B light. CYP-cytochrome P450 enzyme.

The genomic actions of VD are mediated by the VDR [9,10]. The VDR is a member of the steroid hormone nuclear receptor family that acts as a transcription factor when activated. VDR has three domains, a C-terminal ligand binding domain for VD binding, an N-terminal DNA binding domain that binds to VD response elements (VDREs) in the promoter region of VD-regulated genes, and a hinge region that binds these domains together $[9,10]$. The VDR generally interacts with a heterodimer partner retinoid- $X$ receptor (RXR) and coactivators/coregulators, increasing translational activity at a range of target genes that allow for multiple and varied responses across different cell types $[2,9,10]$. 
$1,25(\mathrm{OH})_{2}-\mathrm{VD}_{2}$ and $\mathrm{VD}_{3}$ also exert rapid non-genomic actions via multiple second messenger pathways [11,12]. These appear to be mediated by both the nuclear VDR, as well as a membrane-bound receptor known as membrane-associated rapid response steroid binding protein (MARRS) [12,13]. These non-genomic actions are of interest as they appear to be implicated in many of the immunomodulatory effects of VD.

Despite the critical role VD plays in health, VD deficiency (VDD) is a common problem worldwide. While definitions are controversial, VDD is generally defined as circulating levels of $25(\mathrm{OH})$-VD below $50 \mathrm{nmol} / \mathrm{L}(<20 \mathrm{ng} / \mathrm{mL})$ [14]. Reported frequencies in some populations are as high as $90 \%[15,16]$. This is concerning given the wide range of physiological actions that appear to be influenced by VD, in particular our evolving understanding of the role of VD in moderating immune function.

VD has a complex role in immune response regulation, both enhancing and suppressing different responses [17]. Emerging evidence suggests a role for VD in modulating inflammation via the inflammasome cascade [18-20]. Part of the innate immune system, inflammasomes are large, multimeric protein complexes that assemble in the cell in response to danger signals [21,22]. While an important part of the immune response, inflammasome activation has been implicated in the pathogenesis of a wide range of human diseases [23]. Through its receptor, VD appears to be able to inhibit inflammasome assembly and attenuate over-zealous inflammatory responses in animal models of disease $[18,20]$.

This review will focus on the specific role VD may play in moderating inflammasome activity, in particular from the nucleotide-binding domain-like receptor protein 3 (NLRP3) inflammasome, and examine the evidence for VD supplementation in conditions where the inflammasome is implicated.

\section{The Nucleotide-Binding Domain-Like Receptor Protein 3 (NLRP3) Inflammasome}

Innate immune function relies upon immune cell detection of pathogens by pattern-recognition receptors (PRRs). Activation of PRRs by highly conserved pathogen-associated molecular patterns (PAMPs) and danger-associated molecular patterns (DAMPs) then leads to downstream effects with production of the signalling proteins interferon- $\alpha$ and $\beta$, and pro-inflammatory cytokines such as interleukins [21].

Inflammasomes form a critical part of this signalling cascade. Inflammasomes are large, multimeric protein complexes that assemble in the cell cytosol after sensing PAMPs or DAMPs [21,22]. Although there are several described inflammasomes, the most well-studied of these is the NLRP3 inflammasome [21,22].

The NLRP3 inflammasome comprises the NLRP3 sensor protein, the apoptosis-associated speck-like (ASC) adaptor protein, and the pro-caspase-1 effector protein. The inflammasome can be activated through both canonical and non-canonical pathways that then lead to the processing and release of interleukin (IL)-1 $\beta$ and IL-18 [21,22].

Canonical activation of the NLRP3 inflammasome is a multi-step process that requires priming and then activation of the inflammasome [21,22]. The first signal comes when PRRs are activated by PAMPs and DAMPs. The toll-like receptor (TLR) family plays a significant role in downstream signalling, for instance, TLR4 activation, which occurs in response to the common Gram-negative bacterial cell wall molecule lipopolysaccharide (LPS) [24]. Transcriptional activation via the nuclear factor kappa-light-chain-enhancer of activated B cells (NF-kB) pathway leads to increased expression of NLRP3 and pro-interleukin $1 \beta$ expression [21,22]. Deubiquitination of NLRP3 mediated by the BRCA1/BRCA2-containing complex, subunit 3 (BRCC-3), also appears to be a critical step in priming to allow for the oligomerisation of NLRP3 with the other subunits of the inflammasome [24,25], and a complex series of other regulatory steps involving the ubiquitination and phosphorylation of both NLRP3 and ASC is not yet fully understood [26].

After priming, inflammasome activation requires a second signal that may be triggered in response to a wide range of stimuli. A recent review proposed the term homeostasis-altering molecular processes (HAMPs) to describe a number of these signals that include altered membrane potential due to potassium efflux or calcium influx, extracellular adenosine triphosphate (ATP) and 
oxidised deoxyribonucleic acid (DNA), lysosomal degradation products, mitochondrial damage due to reactive oxygen species (ROS), altered mitochondrial membrane potential, and oxidised mitochondrial DNA [27].

Once the inflammasome is activated, the conformational changes induced by oligomerisation activate caspase 1 , which then cleaves pro-IL $1 \beta$ and 18 to release their active cytokine forms [21,22]. Caspase 1 is also able to cleave gasdermin D (GSDMD), the activated form of which translocates to the membrane creating pores that can mediate pyroptosis-a lytic and inflammatory type of programmed cell death—and allow for the release of IL-1 $\beta$ and 18 into the surrounding environment [28-30]. This process is outlined in Figure 2.

Signal 1

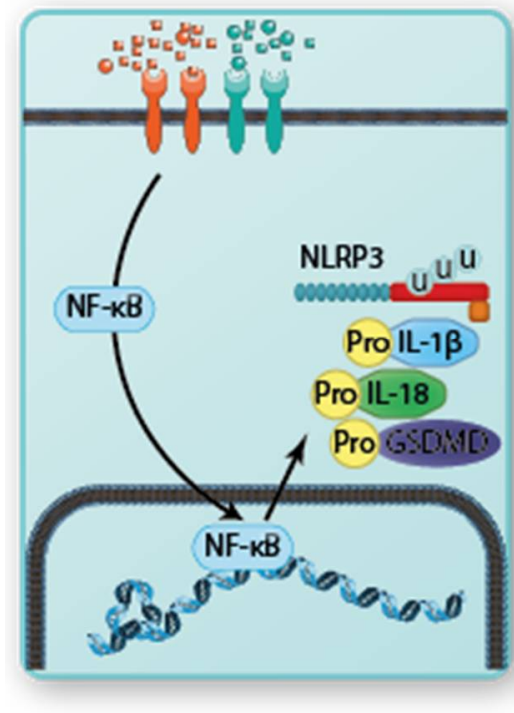

(a)

\section{Signal 2}

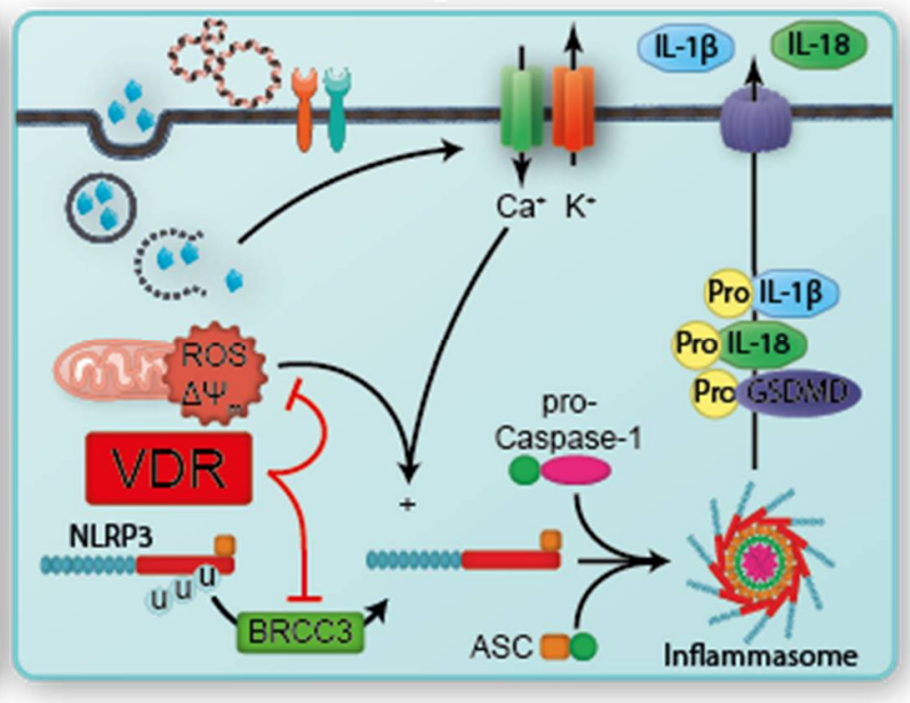

(b)

Figure 2. The canonical inflammasome activation pathway. (a) Signal 1 involves the activation of cell-surface PRRs by PAMPs and DAMPs. This activates downstream signalling with translocation of NF-kB to the nucleus and upregulation of the expression of NLRP3, pro-IL-1 $\beta$, pro-IL-18, and pro-GSDMD. (b) Signal 2 involves activation of the primed components by a range of PAMPs/DAMPs/HAMPs that include extracellular oxidised DNA, extracellular ATP, lysosomal degradation products, calcium influx and potassium efflux, mitochondrial damage with altered membrane potential, and the release of oxidised mitochondrial DNA. BRCC-3-mediated deubiquitination of NLRP3 allows for the activation and oligomerisation of NLRP3 with ASC and pro-caspase-1. After oligomerisation, conformational change activates caspase-1, allowing cleavage and release of IL-1 $\beta$, IL-18, and GSDMD. GSDMD translocates to the cell membrane where it allows for rapid release of IL-1 $\beta$ and IL-18 into the external environment and mediates pyroptosis. PRR - pattern-recognition receptor. PAMP - pathogen-associated molecular pattern. DAMP—danger-associated molecular pattern. HAMP—homeostasis-altering molecular process. NF-kB - nuclear factor kappa-light-chain-enhancer of activated B cells. NLRP3—nucleotide-binding domain-like receptor protein 3. IL-interleukin. GSDMD—gasdermin D. ATP—adenosine triphosphate. DNA-deoxyribonucleic acid. BRCC-3-BRCA1/BRCA2-containing complex, subunit 3. ASC-apoptosis-associated speck-like protein. Adapted from Giuliani et al. with permission from publisher [31].

Noncanonical NLRP3 inflammasome activation can occur in the absence of a priming signal through the activation of murine caspase 11 (or the human equivalents caspase 4 or 5) [32]. Interferon signalling increases the expression of pro-caspase-11 that subsequently activates the NLRP3 inflammasome and pyroptosis. Gram-negative bacterial products such as lipopolysaccharide 
are strong activators of caspase 11 and in animal models, an absence of caspase 11 attenuates the inflammasome response to several Gram-negative bacteria such as Escherichia coli [21,22,32].

Disordered inflammation is implicated in the pathogenesis of an extraordinary range of human diseases, and as our understanding of the inflammasome continues to grow, it has become clear that the inflammasome plays a significant pathological role [21]. Mutations in NLRP3 can lead to a heterogeneous group of cyclical fever syndromes known as cryopyrin-associated periodic syndromes (CAPS) [33]. Inappropriate inflammasome activation may affect outcomes from infections including respiratory tract infections (such as the novel coronavirus, Mycobacterium tuberculosis, and bacterial pneumonias). Increasingly, inflammasomes are also being linked to autoinflammatory conditions, where the inflammasome may be the initiator or exaggerator of inflammatory responses. These include neurodegenerative conditions (multiple sclerosis, Alzheimer's disease, and Parkinson's disease), rheumatological conditions (gout, rheumatoid arthritis, psoriatic arthritis), and metabolic conditions (obesity, atherosclerotic cardiovascular disease, and diabetes mellitus) [21,23].

\section{Vitamin D and the Emerging Role in Immunity}

Innate and adaptive immune responses to infection involve complex and dynamic interactions between a wide array of immune cell types, cell-bound and free signalling molecules, chemokines, and hormones [34]. VD interacts with both the innate and adaptive immune responses in a complex manner, which can upregulate and enhance some responses, while attenuating others and encouraging the differentiation of regulatory T cells [17].

The innate immune system relies on a system of PRRs that respond to PAMPs [34]. TLRs are the major sensing molecule on the cell surface of innate immune cells, such as polymorphonuclear cells, monocytes, and macrophages [35]. This large family of transmembrane PRRs respond to a wide range of highly conserved PAMPs such as cell wall molecules (e.g., lipopolysaccharide, peptidoglycans) and RNA/DNA sequences [35]. Activation of TLRs leads to the downstream production of antimicrobial peptides (AMPs) that provide a rapid defence from pathogens [35].

$1,25(\mathrm{OH})_{2}-\mathrm{VD}_{3}$ promotes the differentiation of monocytes into macrophages in both murine and human cells [36,37]. Furthermore, VD plays a major role in enhancing the mechanisms of pathogen elimination. Macrophages and monocytes possess an intracrine machinery for local VD activation, allowing intracellular VDR signalling and transcription of important AMPs such as cathelicidin [38] and beta-defensin-2 [39], implicated in host immune response to bacteria (e.g., Mycobacterium tuberculosis) and viruses [17]. On the other hand, $1,25(\mathrm{OH})_{2}-\mathrm{VD}_{3}$ was found to suppress the differentiation of monocytes into dendritic cells, even when activated by profound stimuli such as LPS, while also inhibiting production of the signalling molecules IL-10 and IL-12 that are important for dendritic cellular function. It is hypothesised that immature dendritic cells and low IL-12 levels can promote the development of regulatory $\mathrm{T}$ cells that suppress inflammation in a tolerogenic state [40].

VD may also act as an inhibitor or suppressor of the adaptive immune system. Adaptive immune responses require a complex series of interactions between antigen presenting cells (APCs), $\mathrm{T}$ lymphocytes, and B lymphocytes [34]. APCs in the form of dendritic cells and macrophages present processed antigen to $\mathrm{T}$ lymphocytes for recognition and clonal selection of appropriately responding cells [34]. These processes are heavily influenced by an array of signalling molecules that modulate $\mathrm{T}$ cell differentiation, $\mathrm{B}$ cell activation, and antibody formation [34]. The anti-inflammatory effect of $1,25(\mathrm{OH})_{2}-\mathrm{VD}_{3}$ is partially mediated by the reduction in cytosolic and nuclear NF-kB protein expression of T lymphocytes [41], as well as by the inhibition of the interferon- $\gamma$-mediated Th1 shift of $\mathrm{T}$ lymphocytes [42]. Moreover, recent studies have also highlighted the direct immunomodulatory role of $1,25(\mathrm{OH})_{2}-\mathrm{VD}_{3}$ in B cells, inhibiting plasma cell differentiation and activation [43]. 


\section{The Intersection of Vitamin D and the Inflammasome}

Inflammasome pathways form an integral role in the innate immune system, and inappropriate inflammasome activity is strongly implicated in an array of human disease. Data from genetic studies suggested a role for the VDR affecting inflammasome activity. Al-Daghri et al. showed that a single nucleotide polymorphism (SNP) in the VDR gene is strongly associated with increased inflammasome activity and circulating levels of IL-1 $\beta$ and IL-18 [44].

This effect appears to be due to a direct interaction between VDR and NLRP3. Huang et al. performed co-immunoprecipitation of VDR and NLRP3 in ex vivo murine CD4+ T cells, showing VDR complexing with NLRP3 in nuclear extracts. These complexes could also be formed in vivo, and appeared to be functionally significant with chromatin precipitation, demonstrating higher NLRP3 and RNA polymerase II activity at the IL-4 locus in VDR knockout cells [19].

Rao et al. further investigated the interaction between VDR and the NLRP3 inflammasome. Notably, co-transfection of VDR with other components of the inflammasome did not find any interaction with either ASC or caspase-1. The interacting elements were found to be the ligand-binding domain of VDR with the amino-terminal pyrin domain of NLRP3 [20]. They further demonstrated that VDR knockout macrophages have increased IL-1 $\beta$ and IL-18 when activated by either the canonical or non-canonical pathways, without a concomitant increase in inflammasome-independent cytokines such as tumour necrosis factor $\alpha$. These effects were then attenuated with the restoration of VDR expression [20].

Deubiquitination of NLRP3 is a critical step in inflammasome activation and the binding of NLRP3 to ASC. BRCC3 is a deubiquitinase that has a crucial role in posttranscriptional activation of NLRP3, the inhibition of which almost completely blocks NLRP3 activation [24]. Rao et al. further demonstrated that the VDR-binding of NLRP3 appears to attenuate BRCC3-mediated deubiquitination of the LRR domain of NLRP3 [20]. This increase in NLRP3 ubiquitination leads to increased protein degradation [18].

Independent of VDR-NLRP3 binding and inhibition, VDR can also increase levels of the mitochondrial membrane protein UCP2 (uncoupling protein-2). This protein directly prevents the production of ROS, and its activity is inhibited by the inflammasome. Cao et al. showed that UCP2 levels were significantly increased when in vitro $1,25(\mathrm{OH})-\mathrm{VD}_{3}$ solution was added to canonically activated macrophage cell cultures [18]. These actions are summarised in Figure 2.

VDR agonists can induce these effects by their actions on the VDR to reduce inflammasome activity. Studies have shown that $25(\mathrm{OH})-\mathrm{VD}_{3}$ and $1,25(\mathrm{OH})_{2}-\mathrm{VD}_{3}$ are both capable of inhibiting NLRP3 inflammasome activation and downstream IL-1 $\beta$ signalling $[20,45,46]$.

These actions seem to be beneficial in multiple models of disease. In in vitro models of air pollution, $1,25(\mathrm{OH})_{2}-\mathrm{VD}_{3}$ attenuated the inflammatory response mediated by $\mathrm{p} 38 / \mathrm{NF}-\mathrm{kB} / \mathrm{NLRP3}$ [47]. In a murine model of liver injury, VDR agonist calcipotriol demonstrated NLRP3-attenuating effects that reduced the severity of liver injury and fibrosis [48]. Similarly, in a murine model of ulcerative colitis, $1,25(\mathrm{OH})_{2}-\mathrm{VD}_{3}$ treatment reduced colonic inflammation, likely due to its anti-inflammasome effects [18]. Meanwhile, a murine model of diabetic retinopathy demonstrated significant downregulation of the NLRP3 inflammasome response in the setting of hyperglycaemia, with a subsequent reduction in apoptosis and preservation of normal retinal structure [49].

\section{Potential Roles for Vitamin D as a Therapeutic Option in Inflammasome Disorders}

VDD is associated with a wide range of disorders, and there is overlap in the prevalence of VDD and a number of inflammasome-mediated conditions (Table 1). In general, the role of VDR activation therapy is limited to treating VDD. There is limited evidence in any population to suggest that supplementing VD to high or supraphysiological levels provides any clinical benefit. We discuss here the evidence for VD supplementation across a range of disorders that are associated with inflammasome activity. 
Table 1. Global prevalence of vitamin D deficiency and other disorders.

\begin{tabular}{lcccccc}
\hline \multicolumn{1}{c}{ Region } & VDD & AD & PD & MS & Obesity & T2DM \\
\hline South Africa & $7-20 \%$ & $0.26 \%$ & $0.03 \%$ & $0.01 \%$ & $28.30 \%$ & $4.50 \%$ \\
\hline South America & $20-59 \%$ & $0.47 \%$ & $0.09 \%$ & $0.02 \%$ & $23.79 \%$ & $5.79 \%$ \\
\hline Australia & $31 \%$ & $0.88 \%$ & $0.17 \%$ & $0.09 \%$ & $29.00 \%$ & $5.70 \%$ \\
\hline USA & $36 \%$ & $1.24 \%$ & $0.22 \%$ & $0.16 \%$ & $36.20 \%$ & $10.30 \%$ \\
\hline Mexico & $38 \%$ & $0.52 \%$ & $0.05 \%$ & $0.01 \%$ & $28.90 \%$ & $10.80 \%$ \\
\hline Russian Federation & $43-64 \%$ & $0.71 \%$ & $0.17 \%$ & $0.07 \%$ & $23.10 \%$ & $7.60 \%$ \\
\hline New Zealand & $56 \%$ & $0.86 \%$ & $0.13 \%$ & $0.56 \%$ & $30.80 \%$ & $5.20 \%$ \\
\hline Europe & $57-64 \%$ & $1.37 \%$ & $0.19 \%$ & $0.09 \%$ & $23.22 \%$ & $6.61 \%$ \\
\hline Corth Africa & $60 \%$ & $0.44 \%$ & $0.05 \%$ & $0.03 \%$ & $25.77 \%$ & $8.93 \%$ \\
\hline Brazil & $61 \%$ & $0.88 \%$ & $0.29 \%$ & $0.22 \%$ & $29.40 \%$ & $9.20 \%$ \\
\hline Asia & $77 \%$ & $0.82 \%$ & $0.06 \%$ & $0.01 \%$ & $22.10 \%$ & $6.40 \%$ \\
\hline Middle East & $78-98 \%$ & $0.93 \%$ & $0.11 \%$ & $0.01 \%$ & $6.02 \%$ & $4.42 \%$ \\
\hline Northern Europe & $90 \%$ & $0.48 \%$ & $0.05 \%$ & $0.04 \%$ & $26.81 \%$ & $9.35 \%$ \\
\hline VDD & $92 \%$ & $1.27 \%$ & $0.19 \%$ & $0.16 \%$ & $21.83 \%$ & $5.52 \%$ \\
\hline
\end{tabular}

VDD—vitamin D deficiency. AD—Alzheimer's disease. PD—Parkinson's disease. MS-Multiple Sclerosis. T2DM-type 2 diabetes mellitus. Table data sourced from [16,17,50-56]. The colour gradient shows increasing prevalence from low (green) to high (red).

\subsection{Neurodegenerative Disease}

Alzheimer's disease, Parkinson's syndrome, and Multiple Sclerosis (MS) have all been associated with inflammasome activity, and there is a clear association between VDD and higher risk of disease or disease progression in each [56-58].

In Alzheimer's dementia, a randomised controlled trial (RCT) of 210 VDD patients compared supplemental $\mathrm{VD}_{3} 800 \mathrm{IU} /$ day for 12 months vs. a placebo. This trial did show that after 12 months of treatment, the VD-treated group had lower circulating disease markers than the placebo (plasma amyloid beta), higher cognitive function, and a higher intelligence quotient [59].

In Parkinson's disease, only two small trials enrolling a total of 72 patients with durations of 6-12 months were analysed in a meta-analysis that found while 25(OH)-VD levels were increased in treatment groups at the end of the study period, there was no significant benefit in any outcome measures [58].

A Cochrane review of VD supplementation in MS identified 12 trials enrolling 933 patients for analysis, with significant risk of bias. There was no evidence of improved MS-related outcomes with VD supplementation in the meta-analysis, but the quality of the evidence is very low, and larger, well-conducted studies are underway [60]

\subsection{Rheumatological Disease}

Strong observational evidence links rheumatoid arthritis disease activity with VDD [61], but there are only a few studies examining the role of VD supplementation. In one interesting study of early disease in 39 patients, the addition of a 300,000 unit dose of $\mathrm{VD}_{3}$ did not change the $\mathrm{T}$ cell subtype or cytokine profile, although interferon and IL-17/23 were chiefly measured [62]. Two other small studies of daily supplementation showed significant pain relief after 3 months of therapy in 121 patients [63], and small but significant functional improvements after 6 months of therapy in 59 patients [64].

In gout, inflammation is mediated primarily through the NLRP3 inflammasome and IL-1 $\beta$. However, there is limited evidence to suggest that gout is associated with VDD, and no trials of supplementation have been conducted.

\subsection{Metabolic Disease}

Observational evidence supports an association between low VD levels and metabolic conditions such as type 2 diabetes mellitus (T2DM) [65], atherosclerotic disease [66,67], and obesity [44,68]. 
Several large, well-conducted trials have been conducted examining a role for VD supplementation in T2DM. A large trial included 2423 patients who met the criteria for pre-diabetes but were not vitamin D-deficient. Patients received either $4000 \mathrm{IU} /$ day of $\mathrm{VD}_{3}$ or a placebo, and while there was a trend towards reduced risk of developing overt T2DM, this did not reach statistical significance [69]. Similarly, in another large trial of 1312 diabetic patients not selected for VDD, supplementation of $2000 \mathrm{IU} /$ day of $\mathrm{VD}_{3}$ versus a placebo did not attenuate the diabetes-associated decline in renal function over 5 years of therapy [70]. However, two meta-analyses have suggested the benefit of VD supplementation on measures of glycaemic control and insulin resistance, albeit with some substantial heterogeneity between studies [71,72].

There are just a few small and heterogeneous studies of $\mathrm{VD}_{3}$ or other $\mathrm{VD}$ analogue supplementation in patients with atherosclerosis, with mixed results ranging from no benefit all the way to significant attenuation of progressive atherosclerotic disease [73-75].

Similarly, only two small pilot studies examining VD supplementation in obesity have been conducted. A pilot study of 18 overweight patients examined the effect of combined low-calorie diet and $25,000 \mathrm{IU} /$ week $\mathrm{VD}_{3}$ versus dieting alone. While there were no differences in weight loss, measures of insulin sensitivity did improve in those treated with $\mathrm{VD}_{3}$ [76]. Meanwhile, a placebo-controlled trial of high-dose 100,000 IU bolus of $\mathrm{VD}_{3}$ followed by 4000 IU/day over 4 months in 65 overweight patients showed no difference in functional outcomes, except in the subgroup of 20 patients with VDD who had a significant and clinically relevant improvement in back pain [77].

\subsection{Infection}

VD supplementation in respiratory tract infections has received significant attention and many trials have been conducted to evaluate the role of VD in respiratory infections.

VDD has been identified as an independent risk factor for active pulmonary tuberculosis infection, with the strongest association at levels below $25 \mathrm{nmol} / \mathrm{L}(<10 \mathrm{ng} / \mathrm{mL})[78,79]$. One very large trial of weekly bolus oral dosing of $\mathrm{VD}_{3}$ in 8851 VDD Mongolian children found no benefit to supplementation over 3 years as a preventative for developing pulmonary tuberculosis, although the event rate was very low $(46 / 8851 ; 0.52 \%)$ [80]. Nine small- to medium-sized RCTs, including a total of 1868 patients, have examined the utility of $25(\mathrm{OH})-\mathrm{VD}_{3}$ supplementation as an add-on therapy in patients who already have active pulmonary tuberculosis [81-83]. There was significant heterogeneity between dosing regimens among the trials (daily dosing, weekly/monthly bolus dosing, oral/intramuscular administration), while a number of trials did not test baseline or posttherapy 25(OH)-VD levels, making comparison and meta-analysis difficult. Four trials demonstrated improved sputum culture conversion [82-85], while three trials did not [81,86,87]. One trial found no difference in mortality, although posttherapy 25(OH)-VD levels remained low [88], while four measured tuberculosis scores, with only one of these showing positive results $[83,85,87,89]$.

There is also evidence of a role for VDD in predisposition to influenza infections. Early evidence came from observations of the seasonal nature of influenza infections [90], and several large cohort studies [91,92] and one meta-analysis [93] have since found an inverse association between VD status and risk of respiratory tract infections. Trials with moderate heterogeneity and significantly varied dosing/administration protocols show possible benefit, the strongest with daily/weekly rather than bolus intermittent monthly dosing.

Given that VD has a wide range of modulating actions on immune activity, it is unclear whether an inflammasome-attenuating response is mediating the apparent effect in these conditions. In tuberculosis, an intact IL-1 $\beta$ signalling response is important for host defence in murine models, but this is independent of NLRP3 inflammasome activation [94], and it is possible that mycobacterial-induced inflammasome activation may promote persistent infection [95]. In respiratory tract infections such as influenza, the innate immune system inflammatory response is crucial to being able to mediate viral clearance and repair [96]. However, dysregulated or excessive inflammasome-mediated responses are 
associated with poor outcomes [96]. In patients with avian influenza, analysis of bronchoalveolar lavage and plasma samples found increased levels of IL-1 $\beta$ and IL-18 were poor prognostic markers $[97,98]$.

It is possible to speculate that VD-mediated inhibition of inflammasome activation might be helpful in the most severe form of infection-sepsis. In sepsis, maladaptive inflammatory responses that would normally be protective become harmful and lead to organ dysfunction [99]. A hallmark of the septic response is high levels of the inflammasome-dependent IL-1 $\beta$ [99].

A medium-sized trial of a mixed intensive care unit (ICU) cohort that included septic patients randomised $475 \mathrm{VDD}$ patients to receive either high-dose pulse $\mathrm{VD}_{3}$ monthly or a placebo. While the main outcomes were not different in the general population, pre-determined subgroup analysis of patients with $25(\mathrm{OH})-\mathrm{VD}$ levels $<30 \mathrm{nmol} / \mathrm{L}(<12 \mathrm{ng} / \mathrm{mL})$ showed significant benefits in mortality at 28 days and lasting until up to 6 months [100].

In this context, there has recently been intense interest in VD supplementation in the setting of severe acute respiratory syndrome coronavirus 2 (SARS-CoV-2) infection, known as COVID-19 [101-103]. One small study has been conducted to date with 76 patients hospitalised with SARS-CoV-2 infection randomised to receive the best available therapy plus either oral $25(\mathrm{OH})-\mathrm{VD}_{3}$ or no additional therapy until the time of discharge. Results were promising with reduced need for ICU treatment with 1/50 vs. $13 / 26$ patients in each group admitted to the ICU $(p<0.001)$ [104].

\section{Conclusions}

It is increasingly clear that the NLRP3 inflammasome plays a significant role in human health and disease. VD is a key immune system regulator that appears to play a significant role in modulating NLRP3 inflammasome activity, inhibiting activation through the actions of the VDR. Randomised controlled trial evidence for VDR activating therapy in inflammasome-associated conditions remains scant and limited by small numbers, variable definitions with lack of selection for VDD, and heterogeneity between dosing protocols. It would be useful for trials to include outcomes that could be easily attributable to inflammasome activity attenuation, such as circulating levels of IL-1 $\beta$ or IL-18. While there does not appear to be a role for supraphysiologic VD supplementation, there is a role for supplementation in deficient patients as it is a well-tolerated and safe therapy.

Author Contributions: Conceptualization, P.H.F.G.; writing-original draft preparation, M.T.; writing一review and editing, M.T. and P.H.F.G.; supervision, P.H.F.G. All authors have read and agreed to the published version of the manuscript.

Funding: This research received no external funding.

Acknowledgments: The authors thank Kurt Giuliani for his assistance in adapting Figure 1.

Conflicts of Interest: The authors declare no conflict of interest.

\section{References}

1. DeLuca, H.F. History of the discovery of vitamin D and its active metabolites. BoneKey Rep. 2014, 3, 479. [CrossRef] [PubMed]

2. Bikle, D.D. Vitamin D metabolism, mechanism of action, and clinical applications. Chem. Biol. 2014, 21, 319-329. [CrossRef]

3. Dusso, A.S.; Brown, A.J.; Slatopolsky, E. Vitamin D. Am. J. Physiol. Renal. Physiol. 2005, 289, F8-F28. [CrossRef]

4. Slominski, A.T.; Kim, T.-K.; Li, W.; Yi, A.-K.; Postlethwaite, A.; Tuckey, R.C. The role of CYP11A1 in the production of vitamin $\mathrm{D}$ metabolites and their role in the regulation of epidermal functions. J. Steroid Biochem. Mol. Biol. 2013, 144, 28-39. [CrossRef] [PubMed]

5. Slominski, A.T.; Kim, T.-K.; Janjetovic, Z.; Brożyna, A.A.; Żmijewski, M.A.; Xu, H.; Sutter, T.R.; Tuckey, R.C.; Jetten, A.M.; Crossman, D.K. Differential and Overlapping Effects of 20,23(OH)2D3 and 1,25(OH)2D3 on Gene Expression in Human Epidermal Keratinocytes: Identification of AhR as an Alternative Receptor for 20,23(OH)2D3. Int. J. Mol. Sci. 2018, 19, 3072. [CrossRef] [PubMed] 
6. Slominski, A.T.; Kim, T.K.; Takeda, Y.; Janjetovic, Z.; Brożyna, A.A.; Skobowiat, C.; Wang, J.; Postlethwaite, A.; Li, W.; Tuckey, R.C.; et al. ROR $\alpha$ and ROR $\gamma$ are expressed in human skin and serve as receptors for endogenously produced noncalcemic 20-hydroxy- and 20,23-dihydroxyvitamin D. FASEB J. 2014, 28, 2775-2789. [CrossRef] [PubMed]

7. Slominski, A.; Kim, T.-K.; Li, W.; Postlethwaite, A.; Tieu, E.W.; Tang, E.K.Y.; Tuckey, R.C. Detection of novel CYP11A1-derived secosteroids in the human epidermis and serum and pig adrenal gland. Sci. Rep. 2015, 5, 14875. [CrossRef] [PubMed]

8. Tongkao-On, W.; Carter, S.; Reeve, V.E.; Dixon, K.M.; Gordon-Thomson, C.; Halliday, G.M.; Tuckey, R.C.; Mason, R.S. CYP11A1 in skin: An alternative route to photoprotection by vitamin D compounds. J. Steroid Biochem. Mol. Biol. 2015, 148, 72-78. [CrossRef] [PubMed]

9. Haussler, M.R.; Jurutka, P.W.; Mizwicki, M.; Norman, A.W. Vitamin D receptor (VDR)-mediated actions of $1 \alpha, 25(\mathrm{OH})_{2}$ vitamin $\mathrm{D}_{3}$ : Genomic and non-genomic mechanisms. Best Pract. Res. Clin. Endocrinol. Metab. 2011, 25, 543-559. [CrossRef]

10. Pike, J.W.; Meyer, M.B. The Vitamin D Receptor: New Paradigms for the Regulation of Gene Expression by 1,25-Dihydroxyvitamin D3. Endocrinol. Metab. Clin. N. Am. 2010, 39, 255-269. [CrossRef]

11. Norman, A.W.; Okamura, W.H.; Hammond, M.W.; Bishop, J.E.; Dormanen, M.C.; Bouillon, R.; Van Baelen, H.; Ridall, A.L.; Daane, E.; Khoury, R.; et al. Comparison of 6-s-cis- and 6-s-trans-locked analogs of 1alpha,25-dihydroxyvitamin D3 indicates that the 6-s-cis conformation is preferred for rapid nongenomic biological responses and that neither 6-s-cis- nor 6-s-trans-locked analogs are preferred for genomic biological responses. Mol. Endocrinol. 1997, 11, 1518-1531. [PubMed]

12. Sequeira, V.B.; Rybchyn, M.S.; Tongkao-On, W.; Gordon-Thomson, C.; Malloy, P.J.; Nemere, I.; Norman, A.W.; Reeve, V.E.; Halliday, G.M.; Feldman, D.; et al. The Role of the Vitamin D Receptor and ERp57 in

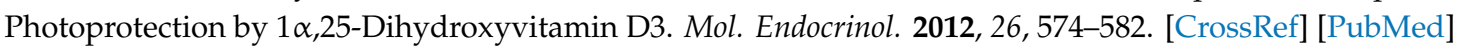

13. Nemere, I.; Farach-Carson, M.C.; Rohe, B.; Sterling, T.M.; Norman, A.W.; Boyan, B.D.; Safford, S.E. Ribozyme knockdown functionally links a 1,25(OH)2D3 membrane binding protein (1,25D3-MARRS) and phosphate uptake in intestinal cells. Proc. Natl. Acad. Sci. USA 2004, 101, 7392-7397. [CrossRef] [PubMed]

14. Holick, M.F. Vitamin D status: Measurement, interpretation, and clinical application. Ann. Epidemiol. 2009, 19, 73-78. [CrossRef]

15. Palacios, C.; Gonzalez, L. Is vitamin D deficiency a major global public health problem? J. Steroid Biochem. Mol. Biol. 2014, 144 Pt A, 138-145. [CrossRef]

16. Van Schoor, N.M.; Lips, P. Global Overview of Vitamin D Status. Endocrinol. Metab. Clin. N. Am. 2017, 46, 845-870. [CrossRef] [PubMed]

17. Gois, P.H.F.; Ferreira, D.; Olenski, S.; Seguro, A.C. Vitamin D and Infectious Diseases: Simple Bystander or Contributing Factor? Nutrients 2017, 9, 651. [CrossRef]

18. Cao, R.; Ma, Y.; Li, S.; Shen, D.; Yang, S.; Wang, X.; Cao, Y.; Wang, Z.; Wei, Y.; Li, S.; et al. 1,25(OH) 2 D 3 alleviates DSS-induced ulcerative colitis via inhibiting NLRP3 inflammasome activation. J. Leukoc. Biol. 2020, 108, 283-295. [CrossRef] [PubMed]

19. Huang, H.; Hong, J.-Y.; Wu, Y.-J.; Wang, E.-Y.; Liu, Z.; Cheng, B.-H.; Mei, L.; Liu, Z.-G.; Yang, P.-C.; Zheng, P. Vitamin D receptor interacts with NLRP3 to restrict the allergic response. Clin. Exp. Immunol. 2018, 194, 17-26. [CrossRef]

20. Rao, Z.; Chen, X.; Wu, J.; Xiao, M.; Zhang, J.; Wang, B.; Fang, L.; Zhang, H.; Wang, X.; Yang, S.; et al. Vitamin D Receptor Inhibits NLRP3 Activation by Impeding Its BRCC3-Mediated Deubiquitination. Front. Immunol. 2019, 10, 2783. [CrossRef]

21. Guo, H.; Callaway, J.B.; Ting, J.P. Inflammasomes: Mechanism of action, role in disease, and therapeutics. Nat. Med. 2015, 21, 677-687. [CrossRef] [PubMed]

22. He, Y.; Hara, H.; Núñez, G. Mechanism and Regulation of NLRP3 Inflammasome Activation. Trends Biochem. Sci. 2016, 41, 1012-1021. [CrossRef] [PubMed]

23. Fusco, R.; Siracusa, R.; Genovese, T.; Cuzzocrea, S.; Di Paola, R. Focus on the Role of NLRP3 Inflammasome in Diseases. Int. J. Mol. Sci. 2020, 21, 4223. [CrossRef] [PubMed]

24. Juliana, C.; Fernandes-Alnemri, T.; Kang, S.; Farias, A.; Qin, F.; Alnemri, E.S. Non-transcriptional Priming and Deubiquitination Regulate NLRP3 Inflammasome Activation. J. Biol. Chem. 2012, 287, 36617-36622. [CrossRef] 
25. Py, B.F.; Kim, M.-S.; Vakifahmetoglu-Norberg, H.; Yuan, J. Deubiquitination of NLRP3 by BRCC3 Critically Regulates Inflammasome Activity. Mol. Cell 2013, 49, 331-338. [CrossRef]

26. Moretti, J.; Blander, J.M. Increasing complexity of NLRP3 inflammasome regulation. J. Leukoc. Biol. 2020. [CrossRef]

27. Liston, A.; Masters, S.L. Homeostasis-altering molecular processes as mechanisms of inflammasome activation. Nat. Rev. Immunol. 2017, 17, 208-214. [CrossRef]

28. Monteleone, M.; Stanley, A.C.; Chen, K.W.; Brown, D.L.; Bezbradica, J.S.; Von Pein, J.B.; Holley, C.L.; Boucher, D.; Shakespear, M.; Kapetanovic, R.; et al. Interleukin-1 $\beta$ Maturation Triggers Its Relocation to the Plasma Membrane for Gasdermin-D-Dependent and -Independent Secretion. Cell Rep. 2018, 24, 1425-1433. [CrossRef]

29. Sborgi, L.; Rühl, S.; Mulvihill, E.; Pipercevic, J.; Heilig, R.; Stahlberg, H.; Farady, C.J.; Müller, D.J.; Broz, P.; Hiller, S. GSDMD membrane pore formation constitutes the mechanism of pyroptotic cell death. EMBO J. 2016, 35, 1766-1778. [CrossRef]

30. Liu, X.; Zhang, Z.; Ruan, J.; Pan, Y.; Magupalli, V.G.; Wu, J.R.V.G.M.H.; Lieberman, J. Inflammasome-activated gasdermin D causes pyroptosis by forming membrane pores. Nature 2016, 535, 153-158. [CrossRef]

31. Giuliani, K.; Kassianos, A.J.; Healy, H.G.; Gois, P.H.F. Pigment Nephropathy: Novel Insights into Inflammasome-Mediated Pathogenesis. Int. J. Mol. Sci. 2019, 20, 1997. [CrossRef] [PubMed]

32. Pellegrini, C.; Antonioli, L.; Lopez-Castejon, G.; Blandizzi, C.; Fornai, M. Canonical and Non-Canonical Activation of NLRP3 Inflammasome at the Crossroad between Immune Tolerance and Intestinal Inflammation. Front. Immunol. 2017, 8, 36. [CrossRef] [PubMed]

33. Booshehri, L.M.; Hoffman, H.M. CAPS and NLRP3. J. Clin. Immunol. 2019, 39, 277-286. [CrossRef] [PubMed]

34. Parkin, J.; Cohen, B. An overview of the immune system. Lancet 2001, 357, 1777-1789. [CrossRef]

35. Takeda, K.; Akira, S. Toll-like receptors. Curr. Protoc. Immunol. 2015, 109, 14.12.1-14.12.10. [CrossRef]

36. Orikasa, M.; Kawase, T.; Suzuki, A. Induction of macrophagic and granulocytic differentiation of murine bone marrow progenitor cells by 1,25-dihydroxyvitamin D3. Calcif. Tissue Int. 1993, 53, 193-200. [CrossRef]

37. Provvedini, D.M.; Deftos, L.J.; Manolagas, S.C. 1,25-Dihydroxyvitamin D3 promotes in vitro morphologic and enzymatic changes in normal human monocytes consistent with their differentiation into macrophages. Bone 1986, 7, 23-28. [CrossRef]

38. Gombart, A.F.; Borregaard, N.; Koeffler, H.P. Human cathelicidin antimicrobial peptide (CAMP) gene is a direct target of the vitamin D receptor and is strongly up-regulated in myeloid cells by 1,25-dihydroxyvitamin D 3. FASEB J. 2005, 19, 1067-1077. [CrossRef]

39. Liu, P.T.; Schenk, M.; Walker, V.P.; Dempsey, P.W.; Kanchanapoomi, M.; Wheelwright, M.; Vazirnia, A.; Zhang, X.; Steinmeyer, A.; Zügel, U.; et al. Convergence of IL-1 $\beta$ and VDR Activation Pathways in Human TLR2/1-Induced Antimicrobial Responses. PLOS ONE 2009, 4, e5810. [CrossRef]

40. Adorini, L.; Penna, G. Dendritic cell tolerogenicity: A key mechanism in immunomodulation by vitamin D receptor agonists. Hum. Immunol. 2009, 70, 345-352. [CrossRef]

41. Yu, X.P.; Bellido, T.; Manolagas, S.C. Down-regulation of NF-kappa B protein levels in activated human lymphocytes by 1,25-dihydroxyvitamin D3. Proc. Natl. Acad. Sci. USA 1995, 92, 10990-10994. [CrossRef]

42. Hewison, M. Vitamin D and the ImmuneSystem: New Perspectives on an Old Theme. Endocrinol. Metab. Clin. N. Am. 2010, 39, 365-379. [CrossRef] [PubMed]

43. Chen, S.; Sims, G.P.; Chen, X.X.; Gu, Y.Y.; Chen, S.; Lipsky, P.E. Modulatory effects of 1,25-dihydroxyvitamin D3 on human B cell differentiation. J. Immunol. 2007, 179, 1634-1647. [CrossRef] [PubMed]

44. Al-Daghri, N.; Guerini, F.R.; Al-Attas, O.S.; Alokail, M.S.; Alkharfy, K.M.; Draz, H.M.; Agliardi, C.; Costa, A.S.; Saulle, I.; Mohammed, A.K.; et al. Vitamin D Receptor Gene Polymorphisms Are Associated with Obesity and Inflammosome Activity. PLoS ONE 2014, 9, e102141. [CrossRef]

45. Dai, Y.; Zhang, J.; Xiang, J.; Li, Y.; Wu, D.; Xu, J. Calcitriol inhibits ROS-NLRP3-IL-1 $\beta$ signaling axis via activation of Nrf2-antioxidant signaling in hyperosmotic stress stimulated human corneal epithelial cells. Redox Biol. 2019, 21, 101093. [CrossRef] [PubMed]

46. Tulk, S.E.; Liao, K.-C.; Muruve, D.A.; Li, Y.; Beck, P.L.; Macdonald, J.A. Vitamin D 3 Metabolites Enhance the NLRP3-Dependent Secretion of IL-1? From Human THP-1 Monocytic Cells. J. Cell. Biochem. 2015, 116, 711-720. [CrossRef] [PubMed] 
47. Xin, L.; Che, B.; Zhai, B.; Luo, Q.; Zhang, C.; Wang, J.; Wang, S.; Fan, G.; Liu, Z.; Feng, J.; et al. 1,25-Dihydroxy Vitamin D(3) Attenuates the Oxidative Stress-Mediated Inflammation Induced by PM(2.5)via the p38/NF-kB/NLRP3 Pathway. Inflammation 2019, 42, 702-713. [CrossRef] [PubMed]

48. Wang, X.; Wang, G.; Qu, J.; Yuan, Z.; Pan, R.; Li, K. Calcipotriol Inhibits NLRP3 Signal Through YAP1 Activation to Alleviate Cholestatic Liver Injury and Fibrosis. Front. Pharmacol. 2020, 11, 200. [CrossRef]

49. Lu, L.; Lu, Q.; Chen, W.; Li, J.; Li, C.; Zheng, Z. Vitamin D3 Protects against Diabetic Retinopathy by Inhibiting High-Glucose-Induced Activation of the ROS/TXNIP/NLRP3 Inflammasome Pathway. J. Diabetes Res. 2018, 2018, 8193523. [CrossRef]

50. Wallin, M.T.; Culpepper, W.J.; Nichols, E.; Bhutta, Z.A.; Gebrehiwot, T.T.; Hay, S.I.; Khalil, I.A.; Krohn, K.J.; Liang, X.; Naghavi, M.; et al. Global, regional, and national burden of multiple sclerosis 1990-2016: A systematic analysis for the Global Burden of Disease Study 2016. Lancet Neurol. 2019, 18, $269-285$. [CrossRef]

51. Nichols, E.; Szoeke, C.E.; Vollset, S.E.; Abbasi, N.; Abd-Allah, F.; Abdela, J.; Aichour, M.T.E.; Akinyemi, R.O.; Alahdab, F.; Asgedom, S.W.; et al. Global, regional, and national burden of Alzheimer's disease and other dementias, 1990-2016: A systematic analysis for the Global Burden of Disease Study 2016. Lancet Neurol. 2019, 18, 88-106. [CrossRef]

52. Dorsey, E.R.; Elbaz, A.; Nichols, E.; Abd-Allah, F.; Abdelalim, A.; Adsuar, J.C.; Ansha, M.G.; Brayne, C.; Choi, J.Y.J.; Collado-Mateo, D.; et al. Global, regional, and national burden of Parkinson's disease, 1990-2016: A systematic analysis for the Global Burden of Disease Study 2016. Lancet Neurol. 2018, 17, 939-953. [CrossRef]

53. Saeedi, P.; Petersohn, I.; Salpea, P.; Malanda, B.; Karuranga, S.; Unwin, N.; Colagiuri, S.; Guariguata, L.; Motala, A.A.; Ogurtsova, K.; et al. Global and regional diabetes prevalence estimates for 2019 and projections for 2030 and 2045: Results from the International Diabetes Federation Diabetes Atlas, 9th edition. Diabetes Res. Clin. Pr. 2019, 157, 107843. [CrossRef] [PubMed]

54. Global Health Observatory, World Health Organisation. Prevalence of Obesity among Adults, BMI $\geq 30$ (Age-Standardized Estimate) (\%) 2017. Available online: https://www.who.int/data/gho/data/indicators/ indicator-details/GHO/prevalence-of-obesity-among-adults-bmi-=-30-(age-standardized-estimate)-(-) (accessed on 7 October 2020).

55. Population Reference Bureau. 2016 World Population Data Sheet. Available online: https://www.prb.org/ 2016-world-population-data-sheet/ (accessed on 7 October 2020).

56. Alfredsson, L.; Armstrong, B.K.; Butterfield, D.A.; Chowdhury, R.; De Gruijl, F.R.; Feelisch, M.; Garland, C.F.; Hart, P.H.; Hoel, D.G.; Jacobsen, R.; et al. Insufficient Sun Exposure Has Become a Real Public Health Problem. Int. J. Environ. Res. Public Health 2020, 17, 5014. [CrossRef] [PubMed]

57. Fitzgerald, K.C.; Munger, K.; Köchert, K.; Arnason, B.G.W.; Comi, G.; Cook, S.; Goodin, D.S.; Filippi, M.; Hartung, H.-P.; Jeffery, D.R.; et al. Association of Vitamin D Levels With Multiple Sclerosis Activity and Progression in Patients Receiving Interferon Beta-1b. JAMA Neurol. 2015, 72, 1458-1465. [CrossRef]

58. Zhou, Z.; Zhou, R.; Zhang, Z.; Li, K. The Association Between Vitamin D Status, Vitamin D Supplementation, Sunlight Exposure, and Parkinson's Disease: A Systematic Review and Meta-Analysis. Med. Sci. Monit. 2019, 25, 666-674. [CrossRef]

59. Jia, J.; Hu, J.; Huo, X.; Miao, R.; Zhang, Y.; Ma, F. Effects of vitamin D supplementation on cognitive function and blood $\mathrm{A} \beta$-related biomarkers in older adults with Alzheimer's disease: A randomised, double-blind, placebo-controlled trial. J. Neurol. Neurosurg. Psychiatry 2019, 90, 1347-1352. [CrossRef]

60. Jagannath, V.A.; Filippini, G.; Di Pietrantonj, C.; Asokan, G.V.; Robak, E.W.; Whamond, L.; Robinson, S.A. Vitamin D for the management of multiple sclerosis. Cochrane Database Syst. Rev. 2018, 9, Cd008422. [CrossRef]

61. Lee, Y.H.; Bae, S.-C. Vitamin D level in rheumatoid arthritis and its correlation with the disease activity: A meta-analysis. Clin. Exp. Rheumatol. 2016, 34, 827-833.

62. Buondonno, I.; Rovera, G.; Sassi, F.; Rigoni, M.M.; Lomater, C.; Parisi, S.; Pellerito, R.; Isaia, G.C.; D'Amelio, P. Vitamin D and immunomodulation in early rheumatoid arthritis: A randomized double-blind placebo-controlled study. PLoS ONE 2017, 12, e0178463. [CrossRef]

63. Gopinath, K.; Danda, D. Supplementation of 1,25 dihydroxy vitamin D3 in patients with treatment naive early rheumatoid arthritis: A randomised controlled trial. Int. J. Rheum. Dis. 2011, 14, 332-339. [CrossRef] [PubMed] 
64. Soubrier, M.; Lambert, C.; Combe, B.; Gaudin, P.; Thomas, T.; Sibilia, J.; Dougados, M.; Dubost, J.-J. A randomised, double-blind, placebo-controlled study assessing the efficacy of high doses of vitamin D on functional disability in patients with rheumatoid arthritis. Clin. Exp. Rheumatol. 2018, 36, 1056-1060. [PubMed]

65. Song, Y.; Wang, L.; Pittas, A.G.; Del Gobbo, L.C.; Zhang, C.; Manson, J.E.; Hu, F.B. Blood 25-Hydroxy Vitamin D Levels and Incident Type 2 Diabetes: A meta-analysis of prospective studies. Diabetes Care 2013, 36, 1422-1428. [CrossRef] [PubMed]

66. Elamin, M.B.; Abu Elnour, N.O.; Elamin, K.B.; Fatourechi, M.M.; Alkatib, A.A.; Almandoz, J.P.; Liu, H.; Lane, M.A.; Mullan, R.J.; Hazem, A.; et al. Vitamin D and Cardiovascular Outcomes: A Systematic Review and Meta-Analysis. J. Clin. Endocrinol. Metab. 2011, 96, 1931-1942. [CrossRef]

67. Nsengiyumva, V.; Fernando, M.E.; Moxon, J.V.; Krishna, S.M.; Pinchbeck, J.; Omer, S.M.; Morris, D.R.; Jones, R.E.; Moran, C.S.; Seto, S.W.; et al. The association of circulating 25-hydroxyvitamin D concentration with peripheral arterial disease: A meta-analysis of observational studies. Atherosclerosis 2015, 243, 645-651. [CrossRef]

68. Pereira-Santos, M.; Costa, P.R.F.; Assis, A.M.O.; Santos, C.A.S.T.; Santos, D.B. Obesity and vitamin D deficiency: A systematic review and meta-analysis. Obes. Rev. 2015, 16, 341-349. [CrossRef]

69. Pittas, A.G.; Dawson-Hughes, B.; Sheehan, P.; Ware, J.H.; Knowler, W.C.; Aroda, V.R.; Brodsky, I.; Ceglia, L.; Chadha, C.; Chatterjee, R.; et al. Vitamin D Supplementation and Prevention of Type 2 Diabetes. N. Engl. J. Med. 2019, 381, 520-530. [CrossRef]

70. De Boer, I.H.; Zelnick, L.R.; Ruzinski, J.; Friedenberg, G.; Duszlak, J.; Bubes, V.Y.; Hoofnagle, A.N.; Thadhani, R.; Glynn, R.J.; Buring, J.E.; et al. Effect of Vitamin D and Omega-3 Fatty Acid Supplementation on Kidney Function in Patients With Type 2 Diabetes: A Randomized Clinical Trial. JAMA 2019, 322, 1899-1909. [CrossRef]

71. Lee, C.J.; Iyer, G.; Liu, Y.; Kalyani, R.R.; Bamba, N.; Ligon, C.B.; Varma, S.; Mathioudakis, N. The effect of vitamin $\mathrm{D}$ supplementation on glucose metabolism in type 2 diabetes mellitus: A systematic review and meta-analysis of intervention studies. J. Diabetes Complicat. 2017, 31, 1115-1126. [CrossRef]

72. Li, X.; Liu, Y.; Zheng, Y.; Wang, P.; Zhang, Y. The Effect of Vitamin D Supplementation on Glycemic Control in Type 2 Diabetes Patients: A Systematic Review and Meta-Analysis. Nutrients 2018, 10, 375. [CrossRef]

73. Wu, Z.; Wang, T.; Zhu, S.; Li, L. Effects of vitamin D supplementation as an adjuvant therapy in coronary artery disease patients. Scand. Cardiovasc. J. 2016, 50, 9-16. [CrossRef] [PubMed]

74. Farrokhian, A.; Raygan, F.; Bahmani, F.; Talari, H.R.; Esfandiari, R.; Esmaillzadeh, A.; Asemi, Z. Long-Term Vitamin D Supplementation Affects Metabolic Status in Vitamin D-Deficient Type 2 Diabetic Patients with Coronary Artery Disease. J. Nutr. 2017, 147, 384-389. [CrossRef] [PubMed]

75. Gepner, A.D.; Haller, I.V.; Krueger, D.C.; Korcarz, C.E.; Binkley, N.; Stein, J.H. A randomized controlled trial of the effects of vitamin D supplementation on arterial stiffness and aortic blood pressure in Native American women. Atherosclerosis 2015, 240, 526-528. [CrossRef] [PubMed]

76. Cefalo, C.M.; Conte, C.; Sorice, G.P.; Moffa, S.; Sun, V.A.; Cinti, F.; Salomone, E.; Muscogiuri, G.; Brocchi, A.A.; Pontecorvi, A.; et al. Effect of Vitamin D Supplementation on Obesity-Induced Insulin Resistance: A Double-Blind, Randomized, Placebo-Controlled Trial. Obesity 2018, 26, 651-657. [CrossRef] [PubMed]

77. Brady, S.R.; Naderpoor, N.; De Courten, M.P.; Scragg, R.; Cicuttini, F.; Mousa, A.; De Courten, B. Vitamin D supplementation may improve back pain disability in vitamin D deficient and overweight or obese adults. J. Steroid Biochem. Mol. Biol. 2019, 185, 212-217. [CrossRef] [PubMed]

78. Nnoaham, K.E.; Clarke, A. Low serum vitamin D levels and tuberculosis: A systematic review and meta-analysis. Int. J. Epidemiol. 2008, 37, 113-119. [CrossRef]

79. Zeng, J.; Wu, G.; Yang, W.; Gu, X.; Liang, W.; Yao, Y.; Song, Y. A serum vitamin D level <25nmol/L pose high tuberculosis risk: A meta-analysis. PLoS ONE 2015, 10, e0126014.

80. Ganmaa, D.; Uyanga, B.; Zhou, X.; Gantsetseg, G.; Delgerekh, B.; Enkhmaa, D.; Khulan, D.; Ariunzaya, S.; Sumiya, E.; Bolortuya, B.; et al. Vitamin D Supplements for Prevention of Tuberculosis Infection and Disease. N. Engl. J. Med. 2020, 383, 359-368. [CrossRef]

81. Daley, P.; Jagannathan, V.; John, K.R.; Sarojini, J.; Latha, A.; Vieth, R.; Suzana, S.; Jeyaseelan, L.; Christopher, D.J.; Smieja, M.; et al. Adjunctive vitamin D for treatment of active tuberculosis in India: A randomised, double-blind, placebo-controlled trial. Lancet Infect. Dis. 2015, 15, 528-534. [CrossRef] 
82. Martineau, A.R.; Timms, P.M.; Bothamley, G.H.; Hanifa, Y.; Islam, K.; Claxton, A.P.; Packe, G.E.; Moore-Gillon, J.C.; Darmalingam, M.; Davidson, R.N.; et al. High-dose vitamin D3 during intensive-phase antimicrobial treatment of pulmonary tuberculosis: A double-blind randomised controlled trial. Lancet 2011, 377, 242-250. [CrossRef]

83. Mily, A.; Rekha, R.S.; Kamal, S.M.M.; Arifuzzaman, A.S.M.; Rahim, Z.; Khan, L.; Haq, A.; Zaman, K.; Bergman, P.; Brighenti, S.; et al. Significant Effects of Oral Phenylbutyrate and Vitamin D3 Adjunctive Therapy in Pulmonary Tuberculosis: A Randomized Controlled Trial. PLoS ONE 2015, 10, e0138340. [CrossRef] [PubMed]

84. Nursyam, E.W.; Amin, Z.; Rumende, C.M. The effect of vitamin D as supplementary treatment in patients with moderately advanced pulmonary tuberculous lesion. Acta Med. Indones 2006, 38, 3-5. [PubMed]

85. Coussens, A.K.; Wilkinson, R.J.; Hanifa, Y.; Nikolayevskyy, V.; Elkington, P.T.; Islam, K.; Timms, P.M.; Venton, T.R.; Bothamley, G.H.; Packe, G.E.; et al. Vitamin D accelerates resolution of inflammatory responses during tuberculosis treatment. Proc. Natl. Acad. Sci. USA 2012, 109, 15449-15454. [CrossRef] [PubMed]

86. Ralph, A.P.; Waramori, G.; Pontororing, G.J.; Kenangalem, E.; Wiguna, A.; Tjitra, E.; Lolong, D.B.; Yeo, T.W.; Chatfield, M.D.; Soemanto, R.K.; et al. L-arginine and Vitamin D Adjunctive Therapies in Pulmonary Tuberculosis: A Randomised, Double-Blind, Placebo-Controlled Trial. PLoS ONE 2013, 8, e70032. [CrossRef]

87. Tukvadze, N.; Sanikidze, E.; Kipiani, M.; Hebbar, G.; Easley, K.A.; Shenvi, N.; Kempker, R.R.; Frediani, J.K.; Mirtskhulava, V.; Alvarez, J.A.; et al. High-dose vitamin D3 in adults with pulmonary tuberculosis: A double-blind randomized controlled trial. Am. J. Clin. Nutr. 2015, 102, 1059-1069. [CrossRef]

88. McHugh, T.; Honeyborne, I. Vitamin D as supplementary treatment for tuberculosis: A double-blind, randomized, placebo-controlled trial. Am. J. Respir. Crit. Care Med. 2009, 179, 843-850. [CrossRef]

89. Salahuddin, N.; Ali, F.; Hasan, Z.; Rao, N.; Aqeel, M.; Mahmood, S.F. Vitamin D accelerates clinical recovery from tuberculosis: Results of the SUCCINCT Study [Supplementary Cholecalciferol in recovery from tuberculosis]. A randomized, placebo-controlled, clinical trial of vitamin D supplementation in patients with pulmonary tuberculosis'. BMC Infect. Dis. 2013, 13, 22. [CrossRef]

90. Hope-Simpson, R.E. The role of season in the epidemiology of influenza. J. Hyg. 1981, 86, 35-47. [CrossRef]

91. Ginde, A.A.; Mansbach, J.M.; Camargo, C.A., Jr. Association between serum 25-hydroxyvitamin D level and upper respiratory tract infection in the Third National Health and Nutrition Examination Survey. Arch. Intern. Med. 2009, 169, 384-390. [CrossRef]

92. Berry, D.J.; Hesketh, K.; Power, C.; Hyppönen, E. Vitamin D status has a linear association with seasonal infections and lung function in British adults. Br. J. Nutr. 2011, 106, 1433-1440. [CrossRef]

93. Martineau, A.R.; Jolliffe, D.A.; Greenberg, L.; Aloia, J.F.; Bergman, P.; Dubnov-Raz, G.; Esposito, S.; Ganmaa, D.; Ginde, A.A.; Goodall, E.C.; et al. Vitamin D supplementation to prevent acute respiratory infections: Individual participant data meta-analysis. Health Technol. Assess. 2019, 23, 1-44. [CrossRef] [PubMed]

94. Dorhoi, A.; Nouailles, G.; Jörg, S.; Hagens, K.; Heinemann, E.; Pradl, L.; Oberbeck-Müller, D.; Duque-Correa, M.A.; Reece, S.T.; Ruland, J.; et al. Activation of the NLRP3 inflammasome by Mycobacterium tuberculosis is uncoupled from susceptibility to active tuberculosis. Eur. J. Immunol. 2012, 42, 374-384. [CrossRef] [PubMed]

95. Liu, C.H.; Liu, H.; Ge, B. Innate immunity in tuberculosis: Host defense vs pathogen evasion. Cell. Mol. Immunol. 2017, 14, 963-975. [CrossRef] [PubMed]

96. Tate, M.D.; Mansell, A. An update on the NLRP3 inflammasome and influenza: The road to redemption or perdition? Curr. Opin. Immunol. 2018, 54, 80-85. [CrossRef] [PubMed]

97. Wang, Z.; Zhang, A.; Wan, Y.; Liu, X.; Qiu, C.; Xi, X.; Ren, Y.; Wang, J.; Dong, Y.; Bao, M.; et al. Early hypercytokinemia is associated with interferon-induced transmembrane protein-3 dysfunction and predictive of fatal H7N9 infection. Proc. Natl. Acad. Sci. USA 2014, 111, 769-774. [CrossRef]

98. Guo, J.; Huang, F.; Liu, J.; Chen, Y.; Wang, W.; Cao, B.; Zou, Z.; Liu, S.; Pan, J.; Bao, C.; et al. The Serum Profile of Hypercytokinemia Factors Identified in H7N9-Infected Patients can Predict Fatal Outcomes. Sci. Rep. 2015, 5, 10942. [CrossRef]

99. Skirecki, T.; Cavaillon, J.-M. Inner sensors of endotoxin-implications for sepsis research and therapy. FEMS Microbiol. Rev. 2019, 43, 239-256. [CrossRef] 
100. Amrein, K.; Schnedl, C.; Holl, A.; Riedl, R.; Christopher, K.B.; Pachler, C.; Purkart, T.U.; Waltensdorfer, A.; Münch, A.; Warnkross, H.; et al. Effect of High-Dose Vitamin D3 on Hospital Length of Stay in Critically Ill Patients With Vitamin D Deficiency: The VITdAL-ICU Randomized Clinical Trial. JAMA 2016, 312, 1520-1530. [CrossRef]

101. Grant, W.B.; Lahore, H.; McDonnell, S.L.; Baggerly, C.A.; French, C.B.; Aliano, J.L.; Bhattoa, H.P. Evidence that Vitamin D Supplementation Could Reduce Risk of Influenza and COVID-19 Infections and Deaths. Nutrients 2020, 12, 988. [CrossRef]

102. Ali, N. Role of vitamin D in preventing of COVID-19 infection, progression and severity. J. Infect. Public Health 2020, 13, 1373-1380. [CrossRef]

103. Meltzer, D.O.; Best, T.J.; Zhang, H.; Vokes, T.; Arora, V.; Solway, J. Association of Vitamin D Deficiency and Treatment with COVID-19 Incidence. medRxiv 2020. [CrossRef]

104. Castillo, M.E.; Costa, L.M.E.; Barrios, J.M.V.; Alcalá-Díaz, J.F.; Lopez-Miranda, J.; Bouillon, R.; Gomez, J.M.Q. Effect of calcifediol treatment and best available therapy versus best available therapy on intensive care unit admission and mortality among patients hospitalized for COVID-19: A pilot randomized clinical study. J. Steroid Biochem. Mol. Biol. 2020, 203, 105751. [CrossRef] [PubMed]

Publisher's Note: MDPI stays neutral with regard to jurisdictional claims in published maps and institutional affiliations.

(C) 2020 by the authors. Licensee MDPI, Basel, Switzerland. This article is an open access article distributed under the terms and conditions of the Creative Commons Attribution (CC BY) license (http://creativecommons.org/licenses/by/4.0/). 